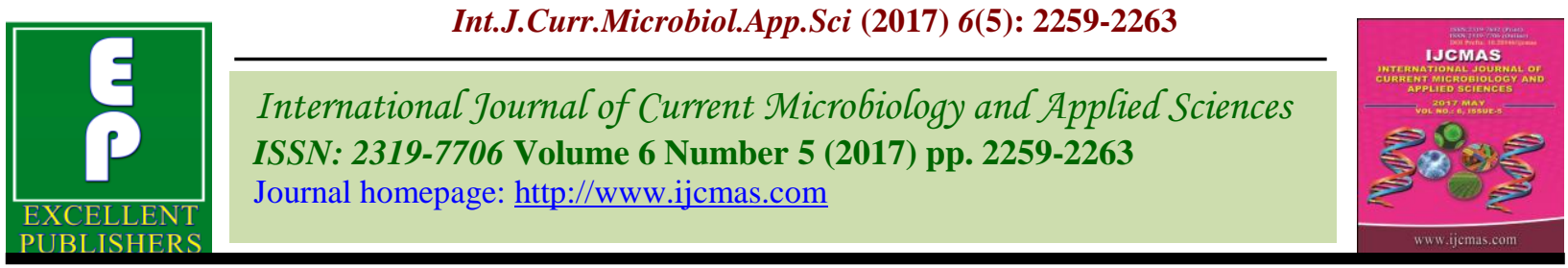

Original Research Article

https://doi.org/10.20546/ijcmas.2017.605.251

\title{
Urinary Tract Infection in Cancer Patients at Government Cancer Hospital Aurangabad, India
}

\author{
Mukta Khaparkuntikar*, Nazneen Siddiqui and Prasanna Bhirud
}

Department of Microbiology, Govt Cancer Hospital and Research Centre, In Front of Amkhas

Maidan, Aurangabad, Maharashtra, India

*Corresponding author:

\begin{tabular}{|c|c|}
\hline & A B S T R A C T \\
\hline Keywords & \multirow{4}{*}{$\begin{array}{l}\text { Urinary tract infection (UTI) is one of the major causes of morbidity in cancer } \\
\text { patients. The purpose of the present study is to analyse the cases of urinary tract } \\
\text { infection and to study their antimicrobial susceptibility pattern. A prospective analysis } \\
\text { of cancer patients in year } 2016-2017 \text { was carried out at Government cancer hospital to } \\
\text { identify the common uropathogens and to know their susceptibility pattern. Out of } 121 \\
\text { samples processed, } 42 \text { were culture positive. Overall E. coli } 16(38.09 \%) \text { was the } \\
\text { predominant pathogen followed by pseudomonas aeruginosa } 08(19.04 \%) \text {, Klebsiella } \\
\text { pneumonia 05 (11.9\%), Candida species } 05(11.9 \%) \text {, Acinetobacter species } 04 \\
\text { (9.52\%), Staphylococcus aureus } 02(4.76 \%) \text {, Enterobacter species } 01(2.3 \%) \text { and } \\
\text { Enterococcus species } 01 \text { (2.3\%). Susceptibility to polymyxin B and colistin was } \\
\text { highest (100\%) followed by the carbapenems (90\%) and piperacillin + Tazobactam } \\
(73 \%) \text {. Resistance to fluroquinolones (96\%), cephalosporins }(80 \%) \text { and } \\
\text { aminoglycosides }(50 \%) \text { was noted. }\end{array}$} \\
\hline $\begin{array}{l}\text { Urinary Tract } \\
\text { Infection, } \\
\text { Antimicrobial } \\
\text { susceptibility } \\
\text { pattern }\end{array}$ & \\
\hline Article Info & \\
\hline Accepted: & \\
\hline
\end{tabular}

\section{Introduction}

Urinary tract infection (UTI) remains the most common hospital associated infection despite the increasing awareness of the dangers of urethral catheterization (Patwardhan, 2006). According to an estimation, about 150 million reports of UTIs per annum were recorded worldwide (Gonzalez et al., 1999). About 35\% of all the UTIs are of nosocomial origin (Mishra et al., 2013). Urinary tract infections are the major cause of morbidity and mortality in patients with malignant diseases due to their several impairments of host defense. General factors in the etiology of UTIs are E. coli and other organisms of the family Enterobacteriaceae. In epidemiological studies, aimed at finding the sources of nosocomial infections, it is important to identify the bacterial species involved. Most of the UTIs are treated empirically, the criteria for the selection of antimicrobial agent should be determined on the basis of the most likely pathogen and its expected resistance pattern in a geographical area (Alabi et al., 2013). Knowledge of infection epidemiology and the institutional resistance pattern can help physicians to select the optimal empirical treatment in critically ill patients (Jeena et al., 2013). The purpose of the present study is to analyse the cases of urinary tract infection in cancer patients and to study their antimicrobial susceptibility pattern. This study will help to 
know the current resistance pattern of uropathogens and to suggest an appropriate empirical treatment.

\section{Materials and Methods}

A prospective analysis of cancer patients suspected to have UTI in period from Jan 2016 to March 2017 was carried out at government cancer hospital Aurangabad. A total of 121 midstream urine samples were received from cancer patients suspected to have UTI for routine and culture examination.

\section{Sample collection}

Precautions were taken in the collection of specimen (mid-stream urine) from each patient, in sterile screw cap wide-neck and leak proof disposable plastic container.

Gross examination: were done for color and turbidity of samples.

\section{Microscopy}

1-2 drops of urine were placed on a clean dry slide and covered with cover slip. The slide was examined by light microscope using high power field for presence of pus cells, red blood cells, epithelial cells, and bacteria.

Isolation method for optimal isolation of causative agent of UTI, CLED and SDA medium were used. Using sterile calibrated loop of 0.001, urine specimens were inoculated on culture media. The plates were incubated at $37^{\circ} \mathrm{C}$ for $18-24$ hours. After incubation, the plates were examined for the presence of significant growth. A bacterial count of $10^{5} / \mathrm{ml}$ or (100 colonies or more in medium) indicates urinary tract infection. Colony morphology of grown microorganisms was studied. More than two colonies of microorganisms were not processed.
Gram stain Gram staining was performed on smear prepared from significant colonies and were examined for gram positive cocci/gram negative bacilli/ yeast cells.

Further identification was done by catalase test, coagulase test, oxidase, IMViC(indole, Methyl Red, Voges Proskauer, Citrate),Triple sugar iron agar, Nitrate reduction and urease. Yeast identification was performed by using germ tube test, corn meal agar and HiChrome candida agar (Koneman et al., 2006).

Antimicrobial susceptibility testing was done by Kirby Bauer disc diffusion test on Muller Hinton agar. 0.5 MacFarland turbidity standard was used for inoculums preparation. Antimicrobial disk were placed on $\mathrm{MH}$ agar and incubated aerobically at $37^{\circ} \mathrm{C}$ overnight. Staphylococcus aureus (ATCC 25923), E. coli (ATCC 25922) and $P$. aeruginosa (ATCC 27853) were used as quality control throughout the study for culture and antimicrobial susceptibility testing. Results of reading were interpreted according to the diameters given in the most recent CLSI (Clinical Laboratory Standard Institute) documents (CLSI, 2016).

For Gram-positive organisms, the antibiotics to be tested and reported were chosen from the following (depending on the organism isolated): Penicillin (10 units), Gentamicin (10mcg) and high level (120mcg), Cefoxitin $(30 \mu \mathrm{g})$, Norfloxacin $(5 \mu \mathrm{g})$, Vancomycin $(30 \mu \mathrm{g} / \mathrm{MIC})$, Linezolid $(30 \mu \mathrm{g})$, and Cotrimoxazole $(1.25 / 23.75 \mu \mathrm{g})$, Nitrofurantoin $(300 \mu \mathrm{g})$. For gram negative organisms the antibiotics for respective organisms were chosen from the following: Gentamicin (10 $\mu \mathrm{g})$, Piperacillin+Tazobactam $\quad(100 / 10 \mu \mathrm{g})$, Polymyxin B (300 units), Colistin $(10 \mu \mathrm{g})$, Norfloxacin $(10 \mu \mathrm{g})$, Nitrofurantoin $(300 \mu \mathrm{g})$, Ceftazidime $(30 \mu \mathrm{g})$, imipenem $(10 \mu \mathrm{g})$ and Cotrimoxazole $(1.25 / 23.75 \mu \mathrm{g})$. 


\section{Results and Discussion}

Out of the 121 urine samples received in microbiology laboratory, $42(34.71 \%)$ yielded positive culture while $20(16.52 \%)$ urine samples showed insignificant growth, 49(40.49\%) cases had no growth and $10(8.26 \%)$ urine samples showed collection contaminants. Out of 42 bacterial isolates, 39 were Gram negative bacilli (GNB) and 03 Were Gram positive cocci (GPC)

Overall E. coli $16 \quad(38.09 \%)$ was the predominant pathogen followed by Pseudomonas aeruginosa 08 (19.04\%),
Klebsiella pneumoniae 05(11.9\%), Candida species 05(11.9\%), Acinetobacter species 04 (9.52\%), Staphylococcus aureus $02(4.76 \%)$, Enterobacter species $01 \quad(2.3 \%)$ and Enterococcus species $01 \quad(2.3 \%)$ which correlates with the results of study conducted by Ramdhan Eldomany et al., (2011).

Amongst the cancer patients $38 \%$ patient showed $E$. coli as commonest isolate. Out of 16 E. coli isolates, $12(75 \%)$ were Extended Spectrum $\beta$ lactamase (ESBL) producer which were $91 \%$ sensitive to imipenem and remaining four were non ESBLs.

Table.1 Bacterial profile of urine culture

\begin{tabular}{|l|l|l|l|}
\hline Sr. No & Organism & Number & Percentage \\
\hline 1. & E.coli & 16 & 38.09 \\
\hline 2. & $\begin{array}{l}\text { Pseudomonas } \\
\text { aeruginosa }\end{array}$ & 08 & 19.04 \\
\hline 3. & Kleibsiella pneumonia & 05 & 11.9 \\
\hline 4. & Candida species & 05 & 11.9 \\
\hline 5. & Acinetobacter species & 04 & 9.52 \\
\hline 6. & $\begin{array}{l}\text { Staphylococcus } \\
\text { aureus }\end{array}$ & 02 & 4.76 \\
\hline 7. & Enterobacter species & 01 & 2.3 \\
\hline 8. & Enterococcus species & 01 & 2.3 \\
\hline
\end{tabular}

Table.2 Percentage of antimicrobial resistance in Gram negative microorganisms

\begin{tabular}{|l|c|c|c|c|c|}
\hline Antibiotics & E. coli & $\begin{array}{l}\text { Pseudomonas } \\
\text { aeruginosa }\end{array}$ & $\begin{array}{l}\text { Klebsiella } \\
\text { pneumonia }\end{array}$ & $\begin{array}{l}\text { Acinetobacter } \\
\text { species }\end{array}$ & $\begin{array}{l}\text { Enterobacter } \\
\text { species }\end{array}$ \\
\hline Ceftazidime & 80 & 75 & 82 & 92 & 71 \\
\hline Colistin & 0 & 0 & 0 & 0 & 0 \\
\hline Cotrimoxazole & 83 & NA & 76 & NA & 80 \\
\hline Gentamicin & 50 & 70 & 75 & 71 & 55 \\
\hline Imipenem & 09 & 10 & 08 & 12 & 07 \\
\hline Nitrofurantoin & 15 & NA & 40 & 40 & 12 \\
\hline Norfloxacin & 90 & 91 & 95 & 96 & 94 \\
\hline $\begin{array}{l}\text { Piperacillin } \\
\text { +Tazobactam }\end{array}$ & 20 & 25 & 30 & 34 & 25 \\
\hline Polymyxin B & 0 & 0 & 0 & 0 & 0 \\
\hline
\end{tabular}

NA: Not Applied 
Fig.1 Cancer type in patients $(\mathrm{N}=42)$

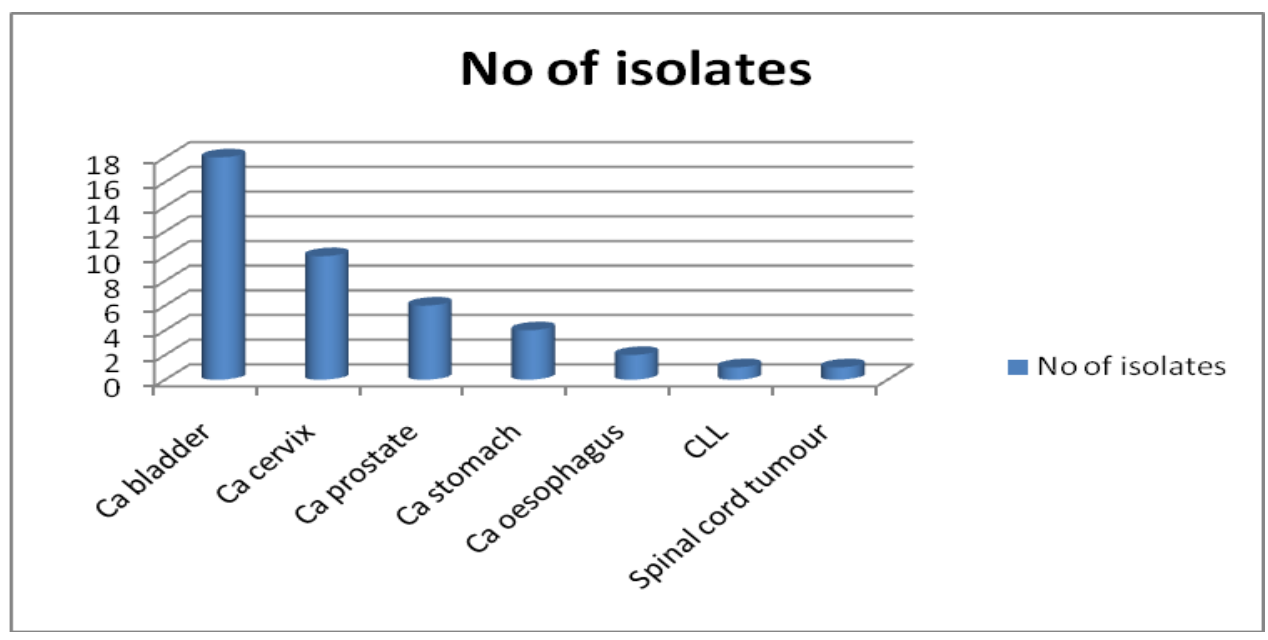

Susceptibility to carbapenem and Piperacillin+Tazobactam of E. coli was $90 \%$ and $73 \%$ respectively. While newer polypeptides like Polymyxin B and colistin were found to be effective against all gram negative bacteria. Refer Table 2 for detailed antibiogram of GNB.

Urinary tract infection (UTI) is the most common bacterial infection. The role of urinary tract infection in cancer patient's etiology is not well established. To gain more insight on the role of urinary tract infection in cancer patient's risk, this study analyzed data from one hundred and twenty one cancer patients.

In this study the culture of urine taken from cancer patients, $34.7 \%$ were positive. This result agrees with the study conducted by Parsad et al., 1995 which revealed an incidence $33.3 \%$. The same finding was reported by (Kouskouni et al., 2005) who showed that the urinary tract infections in patients with malignancies were $33.4 \%$

In our study, E. coli 16 (38.09\%) was the predominant pathogen followed by pseudomonas aeruginosa 08(19.04\%), Klebsiella pneumoniae 05 (11.9\%), Candida species $05(11.9 \%)$, Acinetobacter species 04 (9.52\%), Staphylococcus aureus 02 (4.76\%), Enterobacter species $01 \quad(2.3 \%)$ and
Enterococcus species 01 (2.3\%). This study correlates with Parikh and Bhat (2015) who showed that E. coli $40 \%$ followed by Klebsiella pneumoniae 25\%, Pseudomonas aeruginosa $11 \%$, Enterococcus species $11 \%$ and Proteus mirabilis $5 \%$.

Antibiotic resistance is a major clinical problem in treating UTI in cancer patients caused by different bacterial pathogens. In our present study most of E. coli were ESBL producers and multidrug resistant which correlates with Monali Mishra et al., (2013). In our study, Polymyxin B and colistin were found to be effective for MDR (Multidrug resistant) gram negative infections in patients with limited therapeutic options by considering its toxicity. These findings matched with other studies (Pastewski et al., 2008; Ray et al., 2007). In our study, UTI due to Acinetobacter showed high degree of resistance to commonly used antibiotics suggesting testing for newer drugs which correlates with study conducted by Gupta et al., (2002). In conclusion, urinary tract infection in cancer patients is a common problem. This study suggests urine culture is very important for cancer patients specially those receiving cancer treatments and to control drug resistance, the use of antibiotics should be restricted and to be given only after doing culture and sensitivity test. 


\section{References}

Alabi, A.S., Frielinghaus, L., Kaba, H., Koster, K., Huson, M.A., Kahl, B.C., et al. 2013. Retrospective analysis of antimicrobial resistance and bacterial spectrum of infection Gabon, Central Africa. BMC Infect Dis., 13: 455[PMCfree article][Pubmed]

CLSI-Clinical and Laboratory Standards Institute. 2016. Performance standards for antimicrobial susceptibility testing. Twenty- second informational supplement. Wayne, PA, USA.

Gonzalez, C.M., Schaeffer, A.J. 1999. Treatment of urinary tract infection: what's old, what's new, and what works. World J. Urol., 17:,372-82.[Pubmed]

Gupta, V., Yadav, A., Joshi, R.M. 2002. Antibiotics resistance pattern in uropathogens. Indian J. Med. Microbiol., 20: $96-8$.

Jeena, J., Debata, N.K., Subhudi, E. 2013. Prevalence of extended spectrum beta lactamase and metallo beta lactamase producing multi drug resistant gram negative bacteria from urinary isolates. Indian J. Med. Microbiol., 31: 420-1. [Pubmed]

Koneman, E.W., Allen, S.D., Janda, W.M., Schreckember, P.C., Winn, W.C. 2006. Koneman's Colour Atlas and text book of Diagnostic Microbiology. 6th edition. Newyork: Lippincott, 1216-1223

Kouskouni, E., Demeridou, S., Logothetis, E., Kaparos, G. \& Baka, S. 2005. 15th European Congress of clinical Microbiology and infectious Diseases Copenhagen/ Denmark.

Mishra, M.P., Debata, N.K., Padhy, R.N. 2013. Surveillance of multidrug resistant uropathogenic bacteria in hospitalized patients in Indian. Asian Pac. J. Trop. Biomed., 3: 315-24. [PMC free article] [Pubmed]

Monali Priyadarsini Mishra, Nagen Kumar Debata, et al. 2013. Surveillance of multidrug resistant uropathogenic bacteria in hospitalized patients in Indian. Asian

Pacific J. Trop. Med., 3(4): 315-324.

Parikh and Bhat. 2015. Urinary tract infection in cancer patients in a tertiary cancer setting in India: microbol spectrum and antibiotic susceptibility pattern. Antimicrobial Resistance and infection Control, 4(Suppl 1):P221.

Parsad, K.N., Pradhan, S. \& Datta, N.R. 1995. Urinary tract infection in patients of gynecological malignancies undergoing external pelvic radiotherapy. Gynecol. Oncol., 57(3): 380-2.

Pastewski, A.A., Caruso, P., Parris, A.R., et al. 2008. Parenteral polymyxin B use in patients with multidrug- resistant gramnegative bacteremia and urinary tract infections: a retrospective case series. Ann Pharmacother., 42(9): 1177-87.

Patwardhan Nita. 2006. Urinary tract infections, Hospital associated infections: Epidemiology, prevention and control $1^{\text {st }}$ ed. Jaypee Brothers Medical Publishers (P) LTD, New Delhi, 127-137.

Ramdhan Eldomany and Naveen, A. Abdelaziz. 2011. Characterization and antimicrobial susceptibility of gram negative bacteria isolated from cancer patients on chemotherapy in Egypt. Arch. Clin. Microbiol., vol. 2No.6: 2.

Ray, Y., Hachem, Roy, F., Chemaly, Corine, A., Ahmar, et al. 2007. Colistin is effective in treatment of infections caused by multidrug resistant Pseudomonas aeruginosa in cancer patients. Antimicrobial Agent and Chemother., vol. 51 no. 6 1905-1911.

\section{How to cite this article:}

Mukta Khaparkuntikar, Nazneen Siddiqui and Prasanna Bhirud. 2017. Urinary Tract Infection in Cancer Patients at Government Cancer Hospital Aurangabad, India. Int.J.Curr.Microbiol.App.Sci. 6(5): 2259-2263. doi: https://doi.org/10.20546/ijcmas.2017.605.251 